\title{
RESPONS APOLOGETIS TERHADAP LIMITED GODISM YANG MEMBATASI PERSONA ALLAH
}

\author{
Aeron F. Sihombing \\ PENDAHULUAN
}

Fenomena-fenomena yang terjadi di dalam kekristenan yaitu: ada seruan yang menyatakan bahwa Allah adalah mahakuasa dan tidak dapat dibatasi oleh apa pun, namun di sisi lain dikatakan bahwa Allah dapat digerakkan oleh orang percaya (Luk.18:1-8); pujian dan penyembahan dilakukan untuk dapat mengenal Allah, dan juga untuk dapat memuaskan kebutuhan spiritual maupun untuk menjawab masalah orang percaya; fenomena Allah berbicara kepada orang percaya secara khusus, yang disebut dengan rhema. Itu merupakan kehendak Allah secara khusus kepadanya; minyak urapan (Mrk.6:12), melaluinya orang percaya dapat disembuhkan dari berbagai penyakit, menyelamatkan orang percaya dari kecelakaan dan sebagai syarat atau kunci untuk pintu masuk ke dalam pintu surga; pemuja nama Yahweh menyatakan bahwa tiada nama Allah selain Yahweh. Sebab, nama ini adalah nama yang suci dan yang paling benar; marketing gereja, yang mana Injil telah dikomersialkan untuk keuntungan gereja. Injil telah diperdagangkan, sehingga menghasilkan untung dan untuk menambah jumlah anggota jemaat. Oleh sebab itu, sistem marketing sekular atau perusahaan digunakan di dalam gereja, sehingga gereja dianggap dan diperlakukan hampir sama seperti perusahaan; orang percaya harus menjadi sukses dan makmur, sebab itu adalah janji Allah terhadap orang percaya kepada-Nya. Fenomena-fenomena ini telah membatasi Allah.

Caranya membatasi Allah adalah dengan menekankan fenomena kuasa mutlak Allah yang dibatasi oleh: peristiwa, tempat 
dan istilah dalam Alkitab yang bersifat luar biasa dan yang dianggap ajaib, di mana harus ditiru secara literal atau huruf-perhuruf dalam praktik keagamaan Kristen. ${ }^{1}$ Ketika dikatakan jangan membatasi kuasa Allah, maka pada saat yang sama, ia telah membatasi Allah dengan literalisasi Alkitab dan pengalaman eksistensinya atau tindakannya yang prakmatis. Hal ini sangat berbahaya bila dilakukan oleh orang-orang percaya di dalam kehidupan keagamaan sehari-hari, sebab akan menciptakan Allah di dalam pandangan, keinginannya dan ukurannya sendiri serta berpusat pada manusia itu sendiri, sehingga Allah menjadi terbatas oleh buatan manusia yang terbatas dan Allah terdirtorsi, mereduksi persona Allah, memberhalakan gagasan tentang Allah dan Allah telah diduniawikan oleh manusia. ${ }^{2}$

Hal inilah tantangan yang dihadapi oleh kaum Injili yang mempertahankan pandangan Ortodoksi. Tantangan tersebut berasal dari dalam kekristenan itu sendiri, yang mana atribut Allah dibatasi, misalnya adalah kemahakuasaan Allah telah direduksi sedikian rupa menjadi Allah yang terbatas, melalui pengalaman eksistensial manusia dengan teks Alkitab.

Di samping itu, hal ini bertentangan dengan kekristenan yang memegang penuh persona Allah yang ortodoks, yang mana Dia adalah Allah yang maha kuasa dan tidak terbatas. Allah berdaulat atas diri-Nya sendiri dan tidak dipengaruhi oleh siapapun, bahkan tidak dapat oleh siapa pun, bahkan oleh ciptaan-Nya sendiri yaitu manusia. Ia bebas untuk melakukan apa saja, memutuskan sesuatu, bertindak dan memberikan sesuatu kepada siapa Dia hendak berikan.

Persona Allah yang independen, bebas dan mutlak merupakan sesuatu niscaya bagi kekristenan. Oleh sebab itu, pembatasan atas kemahakuasaan Allah oleh Limited Godism akan berdampak kepada

1 Togardo Siburian, "Mencermati Gagasan-Gagasan Membuat Allah pada Masa Kini dan Reaffirmasi Allah Tritunggal," dalam Soli Deo Gloria dan Pergumulannya Masa Kini, (ed) Togardo Siburian (Bandung: STT Bandung, 2010) 93. 
persona Allah, yaitu kepada eksistensi Allah, esensi Allah dan atribut-atribut Allah yang lain.

Oleh sebab itu, penulis berusaha merespons dengan apologetika melalui artikel ini.

\section{Fenomena-fenomena Membatasi Kuasa Allah dalam Limited Godism}

Kata membatasi Allah (di dalam penggunaan tesis ini) di dalam bahasa Indonesia tidak memiliki arti yang spesifik, karena kata tersebut sulit untuk membedakan membatasi Allah di dalam pemikiran, tindakan atau perbuatan, fenomena, pengalaman maupun di dalam keagamaan. Oleh sebab itu, kata yang cukup jelas untuk membedakannya adalah dengan mengunakan kata bahasa Inggris yaitu limited.

Kata limited artinya adalah hal atau garis yang melampaui sesuatu yang tidak dapat diperluas. Hal ini berhubungan dengan tempat atau lokasi tertentu. ${ }^{3}$ Ruang dan waktu sangat terkait satu dengan yang lain, karena waktu sudah terkait didalamnya, sehingga cakupannya lebih luas. Ketika Allah menciptakan langit dan bumi atau ruang, maka pada saat itu atau secara spontan waktu juga ada atau mengikut didalamnya. Kata limited lebih bersifat konkret, yang terdapat di dalam ruang atau tempat tertentu.

Penggunaan kata Limited Godism adalah membatasi Allah atau Allah yang terbatas ${ }^{4}$. Kata Allah (God) di dalam Limited Godism adalah kata Allah yang terdapat di dalam Perjanjian Lama, maupun Perjanjian Baru, yaitu Allah atau Godism yang terdapat di dalam kekristenan, yang mana tidak perlu lagi dipertanyakan tentang eksistensinya. Allah yang menyatakan diri-Nya kepada orang percaya, melalui wahyu-Nya yang terdapat di dalam Alkitab, untuk

3 A.S.Hornby, Oxford Anvanced Learner's Dictionary (Oxford: Oxford University Press, 2000) 724.

4 Geisler mengunakan istilah Finite Godism. (Norman Geisler dan Ron Brooks, Ketika Alkitab Dipertertanyakan, terj.,Johny The (Yogyakarta: ANDI Offset, 2008). 
menyelamatkan manusia dari dosa dan maut. ${ }^{5}$ Allah yang mengadakan dan memberikan perjanjian atau kovenan terhadap umat-Nya. ${ }^{6}$ Dengan demikian, Limited Godism khusus pada Kristen dan tidak termasuk agama-agama yang lain atau pemikiranpemikiran yang lain mengenai Allah atau Tuhan, sehingga ia hanyalah di dalam Kekristenan, yaitu Allah Tritunggal yang mengadakan perjanjian dengan umat-Nya.

Ia membatasi Allah di dalam ruang atau tempat, yang mana waktu juga tercakup di dalamnya. Sebab, waktu ada atau muncul, ketika ruang atau tempat (space) telah diciptakan oleh Allah. Allah dibatasi dengan huruf, kata, teks, pengalaman, doa, iman, peristiwaperistiwa dalam alkitab yang luar biasa dan yang lainnya. Ia telah membatasi keabsolutan atau kemutlakan Allah.

Limited Godism hanya digunakan pada ranah keagamaan, yaitu membatasi Allah di dalam ibadah, seperti pujian dan penyembahan, yang dapat merayu Allah, doa, pengalaman spektakuler bersama dengan Allah, mukjizat kesembuhan, iman dan literalisasi teks Alkitab.

Dengan demikian, penekanan Limited Godism adalah lebih konkret dan tidak bersifat abstrak yang hanya berada dalam ranah pemikiran. Hal ini ditunjukkan melalui melokalisir Allah di dalam suatu tempat tertentu, memaksa Allah untuk hadir segera di dalam ibadahnya, merayu maupun membujuk Allah, membatasi Allah di dalam teks, nama, tulisan.

Jadi, Limited Godism adalah pembatasan Allah di dalam ranah Kekristenan yang dilakukan secara konkret di dalam kehidupan keagamaan yang dilakukan dengan menggunakan Alkitab. Hal ini dilakukan bukan dengan abstrak atau sebatas teori, melainkan dengan kehidupan keagamaan praktis sehari-hari, misalnya di dalam ibadah. Ia ada atau merasuki di dalam seluruh aspek kekristenan.

5 G.W. Bromiley, "God", di dalam The International Standard Bible Encyclopedia, (ed) G.W. Bromiley (Grand Rapids: William B.Eerdmas Publishing Company, 1982) 489.

${ }^{6}$ H.H.G. Robinson, "God", di dalam A New Dictionary of Christian Theology, (eds) Alan Richardson dan John Bowden (London: SCM Press, 1983) 562. 


\section{Fenomena-Fenomena Limited Godism Tentang Allah}

Limited Godism percaya bahwa Allah berdaulat dan mahakuasa. Ia mengakui bahwa Allah adalah mahakuasa dan berdaulat. Ia adalah Allah yang bebas dan tidak terikat oleh apa pun. Namun, Allah justru dibatasi dengan cara membekuknya atau memenjarakannya di dalam teks Alkitab atau yang disebut dengan meliteralisasi teks alkitab secara ekstrim, melalui pengalaman eksistensialis yang subjektif, yang mana yang ditekankan adalah fenomena kuasa mutlak ilahi atau Allah yang dibatasi oleh waktu, dunia, proses, pengetahuan, kehendak manusia, nama diri, peristiwa, tempat dan istilah atau kata-kata dari dalam Alkitab yang bersifat luar biasa atau spektakuler dan dianggap ajaib. ${ }^{7}$ Peristiwa hebat dan luar biasa tersebut ditiru dan dilakukan sesuai dengan teks yang tertulis di dalam Alkitab tersebut, bahkan dijadikan suatu pembenaran bagi ajarannya dan ini dijadikan suatu ajaran yang normatif atau universal bagi orang Kristen. ${ }^{8}$

Pengalaman berjumpa dengan Allah merupakan kebutuhan dari manusia sekarang untuk meningkatkan iman dari orang percaya dan untuk menjawab permasalahan-permasalahan yang dihadapi oleh manusia. Hal ini lebih baik atau lebih penting daripada dogma yang dianggap kaku dari kekristenan pada jaman sekarang ini.

Beberapa oleh gagasan Limited Godism mengenai Allah yang terjadi pada saat ini, yaitu: 1) pujian dan penyembahan untuk memuaskan ego manusia, karena dianggap sangat penting, di dalam pengenalan akan Allah serta untuk memuaskan spiritual atau rohani ${ }^{9}$ dan juga untuk menjawab segala kebutuhan yang dimiliki

${ }^{7}$ Siburian, Mencermati ..., 91-93.

${ }^{8}$ Donald W.McCullough, The Trivialization of God-The Dangerous Illusion of $A$ Manageable Deity (Collorado: Navpress, 1988) 35.

9 Tommy Tenney, The God Chases, My Soul Follow Hard After These (Shippenburg: Destiny Image Publisher, 2000). 
oleh orang percaya. ${ }^{10}$ Di samping itu, untuk menikmati pengalaman pertemuan dengan Allah yang transcenden; 2) pendeta harus dapat menyanyi (bawa pujian) untuk mendapatkan urapan daripada Allah dan tidak cukup hanya khotbah; 3) rhema dengan fenomenal alkitabiah yang melahirkan wahyu baru ${ }^{11}$; 4) doa dapat mengubah kehendak Allah dan masa depan manusia ${ }^{12}$; 5) mukjizat dan kesembuhan kewajiban dari Allah untuk melakukannya kepada orang percaya ${ }^{13}$; 6) persembahan ekonomis dengan prinsip take and give, yang menyatakan bahwa apabila orang percaya memberikan yang besar atau yang banyak kepada Allah, maka ia akan memperoleh lagi sesuatu yang lebih besar ${ }^{14}$, bahkan lebih dari 10 kali lipat. Di samping itu, ia akan dapat memiutangi Allah dengan persembahan yang diberikan; 7) minyak urapan dan Perjamuan Kudus sebagai sumber berkat dan juga dapat menyembuhkan penyakit bagi orang percaya (Yak.5:14-16) ${ }^{15}$; 8) kesuksesan tanda dari orang yang beriman, sebaliknya orang yang miskin dianggap sebagai orang yang tidak diberkati, bahkan dihukum oleh Allah ${ }^{16}$; 8) lompatan iman yang buta, yang mana secara literalisasi membaca cerita Alkitab dan langsung beriman secara buta untuk mempercayai peristiwa apa yang terjadi, sehingga ia berusaha un tuk memaksa Allah melakukan apa yang dikehendaki olehnya ${ }^{17}$.

10 John Ortberg, If You Want to Walk on Water, You've Got to Get Out of the Boat (Michigan: Zondervan Publishing House, 2000) 196-198.

${ }^{11}$ Silalahi, Kharismatik ..., 63.

${ }^{12}$ Dean Sherman, Spiritual Warfare for Every Christian (Seattle: Youth With A Mission, 2001) 170.

${ }^{13}$ Ken Blue, Otoritas untuk Menyembubkan (Jakarta: Yayasan Pancar Pijar Alkitab, 2010) 82.

14 Pernyataan ini dikutip dari seorang pengkhotbah yang bernama Pdt. Yustinus Ardianto Pr, pada 13 Pebruari 2011, di gereja Fresh Anointing, Bandung.

${ }^{15}$ Dikutip dari: Buletin Mingguan Tiberias, Warta Mingguan, No.1156, Minggu, 30 Januari 2011.

16 Pernyataan ini dikutip dari seorang pengkhotbah yang bernama Pdt. Yustinus Ardianto Pr, pada 13 Pebruari 2011, di gereja Fresh Anointing, Bandung.

${ }^{17}$ Paul Yonggi Cho, Lompatan Iman (Jakarta: Immanuel, t.t.) 153-173. 
Kuncinya adalah hanya beriman kepada Allah, yang mana ini adalah tugas darinya ${ }^{18}$; 9) pemuja nama Yahweh, yang dianggap sebagai nama yang otentik dari pada Allah dan nama Allah dianggap sebagai Allah orang penyembah berhala ${ }^{19}$; 10) marketing gereja untuk keuntungan, yang mana merupakan suatu usaha manusia untuk memajukan gereja dengan melihat untung dan rugi ${ }^{20}$; 11) baptisan harus dengan selam dan baptisan yang lain dianggap salah ${ }^{21}$.

Maka, prinsip interpretasi Limited Godism adalah 1) pengalaman eksistensialis berdasarkan persepsi subjektif ${ }^{22}$; 2) literalisasi teks Alkitab $^{23}$; 3) eisegesis hermeneutik ${ }^{24}$; 4) bibliosentris tetapi tidak skriptural, yang hanya mengutip ayat Alkitab, tanpa sistem teologi yang benar, sehingga menafsirkan teks Alkitab secara sembarangan; 5) spiritualisasi teks Alkitab; 6) pragmatisasi praktis untuk keuntungan pribadi ${ }^{25}$

Dengan demikian, konsep Allah menurut Limited Godism adalah: $\left.{ }^{26} 1\right)$ pengalaman dengan Allah dianggap sebagai wahyu baru; 2) Allah dijadikan User Friendly Godism ${ }^{27}$; 3) keterbukaan Allah

18 Ibid.

19 Kitab Suci, Indonesia Literal Translation (Jakarta: Yayasan Lentera Indonesia, 2008).

20 K.C. Price, Saran-Saran Praktis untuk Pelayanan yang Berhasil (Jakarta: Immanuel, 1993).

21 Dikutip dari: Buletin Mingguan Tiberias, Warta Mingguan, No.1156, Minggu, 30 Januari 2011.

22 F.L. Arrington, "Hermeneutics, Historical Perspectives on Pentacostal and Charismatic," dalam Dictionary of Pentacostal and Charismatic Movement, (eds)Stanley M.Burges dan Gary B. Mc Gee (Grand Rapids: Zondervan Publishing House, 1995) 378.

23 Ibid.

24 Siburian, Sola Scriptura ..., 20.

25 Fee, Gospel ..., 86-87.

26 Togardo Siburian, Isu-Isu Kontemporer dalam Doktrin Allah, Classnote, STTB (Indonesia) Bandung, 2009.

${ }^{27} \mathrm{Hal}$ ini berdampak atau pengaruh terhadap konsep tentang Allah, bukan terhadap Allah secara ontologis. Allah dijadikan sebagai alat atau "user friendly God". Misalnya adalah seperti: a) Allah yang menjadi seperti Santa Claus yang baik hati, yang mana ia selalu memberikan hadiah kepada anak-anak yang baik 
terhadap manusia, yang mana Ia sengaja melibatkan manusia, dengan cara bekerjasama dari manusia; 4) take and give, yang mana Allah menunggu sesuatu apa yang akan diperbuat oleh manusia kepada-Nya. Apabila manusia telah memberikan sesuatu kepada Allah, yaitu berupa persembahan materi atau tenaga, pujian, ibadah dan yang lainnya, maka Allah akan mendatangkan berkat yang besar kepadanya.

Dengan demikian ditemukanlah world view dari Limited Godism, yaitu: ${ }^{28}$ 1) sekularisme, yang mana manusia memisahkan diri dengan Allah, yang mana ia otonom atau berdiri sendiri dengan akalnya. ${ }^{29}$ 2) rasionalisme, yang mana akal atau rasio manusia sebagai ukuran dari kebenaran. ${ }^{30}$ Manusia mengukur segala sesuatu berdasarkan persepsi, image maupun pengalaman eksistensialnya. Dengan itulah, dia menciptakan konsep Allah; 3) eksistensialisme, penekanannya adalah eksistensi individu yang subjektif, sebab manusia adalah ukuran dari segala sesuatu, sebab ia adalah otonom

hati dan yang tidak nakal; b) tukang ilahi atau a beavenly repair man. Allah dipandang hanya sebagai tukang yang memperbaiki kehidupan manusia yang rusak. Hal ini merupakan tugas Allah terhadap manusia; c) kakek yang baik hati (a galactic grandfather), kakek yang sangat pengasih dan penyayang terhadap cucucucunya, yang mana ia penuh dengan cinta, namun kurang dalam mendisplin atau ia tidak pernah menghukum. Apabila cucunya melakukan kesalahan, ia hanya tersenyum dan tidak akan mendisplinnya. Ia selalu berusaha menyenangkan cucu-cucunya; d) Allah seperti jin Aladin, yang bila dipanggil akan datang dan keluar dari tempat persembunyiannya, serta memenuhi apa yang menjadi keinginan dari manusia tersebut.

${ }^{28}$ World view adalah suatu komitmen, suatu orientasi hati yang mendasar, yang dapat diekspresikan sebagai suatu kisah atau dalam seperangkat presuposisi (asumsi-asumsi yang mungkin benar, separuh benar, atau sama sekali salah) yang dianut oleh seseorang (dengan sadar atau tidak sadar, dengan konsisten atau tidak konsisten) mengenai susunan dasar realitas, dan yang memberikan fondasi di mana ia hidup, bergerak dan memiliki keberadaan (James Sire, Semesta Pemikiran: Sebuah Katalog Wawasan Dunia Dasar (Surabaya: Momentum, 2005).

${ }^{29}$ Harry Blamires, Mengenal Wawasan Kristen (Surabaya: Momentum, 2004).

30 V. James Mannonoia, "Rasionalisme dan Empirisme", di dalam Membangun Wawasan Dunia Kristen (eds) W.Andrew Hoffecker dan Gary Scott Smith (Surabaya: Momentum, 2006) 277. 
atau berdiri sendiri ${ }^{31}$ dan juga menekankan secara total subjektif dari manusia, yaitu perasaan, emosi, suasana hati dan yang lainnya ${ }^{32}$; 4) pragmatisme, mentalitas berpikir pragmatis adalah yang terpenting adalah kegunaan atau manfaat dari sesuatu. ${ }^{33}$

\section{Prinsip-Prinsip Apologetis Injili Mengenai Ketidakterbatasan Allah}

Apologetika merupakan suatu studi secara sistematis di dalam pertanggungjawaban iman orang percaya. Karena, apologetika dilakukan secara konsisten, koheren, kongruen dan komprihensif. Apologetika sebagai tempat untuk mengolah atau merumuskan ulang pernyataan dari iman Kristen di dalam setiap konteks atau pergumulan yang dihadapi di sepanjang zaman. Tugas dari apologetika adalah:

sebagai pemurnian iman Kristen ${ }^{34}$ dan sebagai suatu sfirmasi iman Kristen ${ }^{35}$.

\section{Presuposisionisme sebagai suatu sistem apologetika}

Pendekatan apologetika di dalam penelitian ini adalah presuposionisme, yaitu yang melakukan pendekatan berdasarkan Alkitab. ${ }^{36}$ Sumber dari pikiran maupun dasar pijak adalahnya Alkitab. Alkitab berotoritas, otonomi dengan berdasarkan Allah Tritunggal. Alkitab dapat membenarkan dirinya sendiri, yang mana ia dapat membuktikan dirinya sendiri, sehingga menjadi sumber yang berotoritas di dalam berapologetika. Fondasinya adalah

31 Chales S. MacKenzie, "Positivisme, Eksistensialisme dan Pragmatisme" dalam Membangun Wawasan Dunia Kristen, ed.W.Andrew Hoffecker (Surabaya: Momentum, 2006) 313-315.

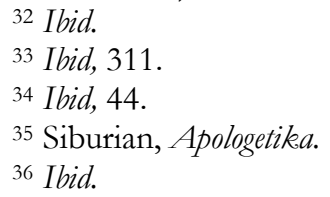


berdasarkan tridadik keselamatan, yaitu: penciptaan, kejatuhan dan penebusan. ${ }^{37}$

Oleh sebab itu, pendekatan presuposisionisme menegaskan kembali iman Kristen yang berlandaskan Alkitab. Dasar dari Sistem Prepusisionisme adalah: ${ }^{38}$ 1) orang yang melakukan apologetika merupakan dasar dari sistem presupisisionisme, yang akan menentukan konsep, metode di dalam apologetika. Syaratnya adalah ia harus lahir baru (Yoh.3:1-16), sehingga ia mengerti akan Alkitab dengan tuntunan dari Roh Kudus (Luk.24:45). Hatinya telah dipengaruhi oleh Roh Kudus, sehingga wawasan dunianya adalah hanya berlandaskan kepada Allah (Kis.16:14); 2) iman adalah anugerah dari Allah, merupakan dasar dari presuposisi dari orang yang melakukan apologetika, sehingga ini merupakan fondasi dari sistem yang dimiliki. Iman merupakan pemberian dari pada Allah, sehingga ini disebut sebagai anugerah kepada orang percaya (Fil.1:29; Ef.2:8). Iman merupan tuntutan dari Roh Kudus, sebab manusia tidak dapat memperolehnya dengan usaha sendiri (Yoh,16:13). Iman akan bertumpu atau mendasarkan diri kepada firman Allah, yaitu di dalam Alkitab. Oleh sebab itu, iman bukanlah lompatan iman atau leap of faith atau iman yang irrasional, karena ia memiliki landasan dan sistem yang jelas.

Presuposisi di dalam sistem pesuposisionisme

Presuposisi di dalam apologetika adalah sesuatu yang mendasari suatu sistem, yang mana konsep akan dikembangkan atau dibangun. Oleh sebab itu, presuposisi dalam apologetika adalah Allah itu sendiri, wahyu Allah yang telah diinskripturasikan sebagai sumber kebenaran adalah: 1) penciptaan; 2) kejatuhan; dan 3) penebusan atau sejarah keselamatan; Di samping itu, iman dan akal yang saling berhubungan satu dengan yang lain.

38 Robert A. Morey, Introduction to Defending the Faith (Newport: Trueseekers, 1989) 7-17. 


\title{
Fondasi Apolegetika Ketidakterbatasan Allah
}

\author{
Wawasan Dunia Injili \\ Wawasan dunia (world view) Kristen sebagai landasan dari \\ teologinya adalah:
}

\section{Allah Tritunggal dasar dari Kekristenan}

Dasar dari pemikiran, dogma dan teologi Kristen adalah Allah ${ }^{39}$ sehingga ini disebut dengan Teisme. Allah adalah realitas utama atau ultimate..$^{40}$ Ia adalah yang mendasari dari segala sesuatu, karena segala sesuatu atau seluruh ciptaan berasal dari pada-Nya. ${ }^{41}$ Semuanya bergantung pada-Nya, sebab ciptaan-Nya tidak kekal.

Allah Teisme Kristen ini adalah Tritunggal, yaitu Bapa, Anak dan Roh. ${ }^{42}$ Allah Tritunggal adalah yang memiliki tiga pribadi, tetapi satu hakekat yaitu keallahan-Nya. Tiga pribadi, yaitu Bapa, sebagai Allah secara umum, yang mana ditujukan sebagai Pencipta langit dan bumi; Anak, sebagai Yesus Kristus yang menyelamatkan manusia, di kayu salib; oknum ketiga adalah Roh Kudus, sebagai yang bekerja menyadarkan orang dari dosa-dosa, melindungi, memelihara, maupun yang menuntun orang percaya kepada Allah. ${ }^{43}$ Hal inilah yang membedakannya dengan Teisme yang lain, seperti teisme filsafat maupun agama-agama yang lain. ${ }^{44}$

Esensi Tritunggal tidak terbagi-bagi satu dengan yang lain. Mereka adalah suatu kesatuan yang tidak dapat dipisahkan. Esensi keallahan dari ketiga pribadi tersebut adalah sempurna di dalam

39 Herman Bavink, Reformed Dogmatics, Prologomena, Vol.1., (Grand Rapids: Baker Academics, 2003) 207.

40 Ronald H. Nash, Konflik. Wawasan Dunia,Mengapa Memilih Wawasan Kekristenan di Tengah Berbagai Pemikiran Dunia, terj. Irwan Tjulianto (Surabaya: Momentum, 2000) 49.

41 Richard L. Pratt Jr., Menaklukekan Segala Pikiran Kepada Kristus, terj.Rahmiati Tanudjaja (Malang: SAAT, 1994) 17.

42 Cornelius Van Til, Christian Apologetics (Phillipsburg: Presbyterian and Reformed Publhishing Co., 1961) 8.

${ }^{43}$ Ibid, 257.

${ }^{44}$ Bavink, God ..., 257. 
diri-Nya sendiri. ${ }^{45}$ Sifat-sifat atau atribut oknum Tritunggal dapat dilihat dari opera ad extra. Hal ini dapat dilihat dari pekerjaan atau tindakan yang telah dilakukan-Nya. Dengan demikian, sifat dari oknum Tritunggal dapat dibedakan. ${ }^{46}$

Gereja sepanjang masa mengakui bahwa ketringgullan Allah sukar untuk dipahami atau dimengerti, sehingga inilah yang disebut sebagai misteri. ${ }^{47}$ Apabila ini dipikirkan, dikaji, dianalisa, maka semakin tidak mengerti dan tidak pahami. Akan tetapi, doktrin ini ada di dalam alkitab dan tidak boleh untuk dihilangkan. Sebab, penolakan terhadap Tritunggal, berarti telah menolak iman Kristen yang paling mendasar atau fundamental. ${ }^{48}$

\section{Allah pemberi kovenan terhadap orang percaya}

Allah ini dikenal sebagai adalah Allah yang membangun atau memberikan kovenan atau perjanjian dengan umat-Nya ${ }^{49}$. Kovenan adalah perjanjian di antara dua belah pihak, yaitu antara tuan dan hamba. ${ }^{50}$ Kovenan yang diberikan Allah kepada umat-Nya merupakan suatu anugerah, sebab manusia seharusnya tidak layak untuk mendapatkannya. Allah sendiri yang memilih dan memberikan kepada kepada umat-Nya, agar umat-Nya menjadi alat untuk menyampaikan berita penebusan dari pada-Nya.

\section{Kedaulatan Allah yang tidak terbatas}

Allah adalah berdaulat, ${ }^{51}$ yang mana Ia menentukan segala sesuatu berdasarkan rencana maupun keputusan-Nya dari kekekalan. Hal ini berhubungan dengan ketuhanan-Nya, yang mana ia adalah Tuhan dan dasar dari segala sesuatu. Atas dasar ini, Ia

\footnotetext{
45 Berkhof, Doktrin ..., 145-157.

46 Ibid, 154.

47 Ibid, 156.

48 Erickson, Christian ..., 322.

49 John M. Frame, Doktrin Pengetabuan tentang Allah (Malang: SAAT, 2004)
} 22.

\section{Ibid.}

51 John M. Frame, Apologetika bagi Kemuliaan Allah, terj.R. Steve Hendra (Surabaya: Momentum, 2009) 22. 
memiliki kontrol, otoritas dan kehadiran. Oleh sebab itu, inilah dasar dari segala sesuatu tindakan Allah dan yang menjadi dasar dari teologi Kristen.

\section{Dasar Pembenaran dari Apologetika}

Arti dari dasar pembenaran atau pengetahuan (yang disebut dengan ontologis) artinya adalah suatu teori tentang ilmu pengetahuan, atau dasar yang mendasari dari ilmu pengetahuan. Apakah dasar dari pembenaran dari Teisme Kristen ${ }^{52}$

\section{Sola Scriptura sebagai dasar pembenaran Injili}

Dasar dari pembenaran dari teologi Injili adalah Alkitab, yang mana ini adalah wahyu atau penyataan Allah yang telah diinskripturasikan kepada orang percaya. Hal ini merupakan pekerjaan dari Roh Kudus, sehingga memiliki otoritas yang mutlak atau absolute. ${ }^{53}$ Sebab, a) ia diiluminasikan oleh Roh Kudus; 3) wahyu Allah di dalam nature dan sejarah; 4) dan wahyu Allah yang disampaikan melalui nabi, rasul dituliskan atau diinscrupturasikan menjadi alkitab. ${ }^{54}$

Dengan demikian, sola scriptura merupakan dasar dari teologi dari Teisme Kristen. Ia menjadi landasan atau fondasi untuk membangun teologi, iman, tindakan, kelakuan atau etika orang percaya.

52Pertanyaan-pertanyaan yang diajukan untuk mengetahui dasar pembenaran dari pengetahuan Injili adalah: dapatkah manusia mempercayai akal sehatnya? apakah peran tepat akal budi dan pengalaman yang masuk akal dalam ilmu pengetahuan? apakah peran tepat akal budi dan pengalaman yang masuk akal dalam ilmu pengetahuan? apakah kebenaran itu relative atau absolute? apakah metode ilmiah adalah merupakan satu-satunya metode pengetahuan? dan yang lainnya (Ronald H. Nash, Iman dan Akal Budi (Surabaya: Momentum, 2001) 45. 20.

${ }^{53}$ John Calvin, Biblical Christianity (London: Grace Publication Trust, 1994)

${ }^{54}$ John Frame, The Doctrine of God, A Theology of God (New Jersey: P\&R Publishing, 2002) 212. 
2. Iman dan rasio sebagai dasar pembenaran Injili

Dasar dari pembenaran Teisme Kristen selain dari wahyu adalah iman dan rasio atau akal dari manusia, yang mana tidak dapat dipisahkan satu dengan yang lain. Iman merupakan unsur yang penting untuk dapat mengetahui atau memahami wahyu Allah yang terdapat di dalam Alkitab, yang mana didalamnya orang percaya dapat mengenal Allah. ${ }^{55}$ Iman adalah kunci masuk untuk mengenal atau mengerti tentang Allah.

Manusia merupakan gambar dan rupa Allah, yang di dalamnya ada juga unsur akal, yang mana tidak dapat dihilangkan dan dibuang begitu saja. Karena, iman dan rasio berjalan dengan beriringan, yang mana rasio akan semakin meneguhkan iman atau membuat iman semakin diperluas, sehingga orang percaya akan semakin beriman. Hal inilah yang dikatakan oleh Paulus, dari iman menuju atau memimpin kepada iman. Dengan demikian, iman merupakan akal yang diperluas ${ }^{56}$

Rasio adalah alat bagi iman atau rasio digunakan untuk membantu iman, agar iman semakin diperjelas. Hal ini merupakan fungsi dari rasio. Akan tetapi, rasio yang telah dipulihkan kembali oleh Allah, sebab karena kejatuhan manusia, rasio telah rusak dan tidak dapat mengenal lagi Allah. Oleh sebab itu, iman dan rasio saling berhubungan dan tidak dapat dipisahkan satu dengan yang lain, sebab akal merupan iman yang diperluas.

\section{Dasar dari Doktrin Ketidakterbatasan Allah}

Allah dengan inisiatif ingin mengungkapkan atau menyatakan diri-Nya kepada manusia (opera ad intra). ${ }^{57}$ Oleh sebab itu, Ia mengkomunikasikan apa yang ada di dalam diri-Nya yaitu apa yang

55 Donald G. Bloesch, Holy Scripture, Revelation, Inspiration and Interpretation (Illinois: InterVarsity Press, 1994) 180.

56 Joseph Tong, Keunggulan Anugerah Mutlak (Bandung: STTB, 2006) 7.

57 Gordon J. Spykman, Reformational Theology, A New Paradigm for Doing Dogmatics (Michigan: W.M.B. Eerdmans Pub. Com, 1991) 75. 
ada di dalam pikiran-Nya maupun apa yang akan direncanakanNya. ${ }^{58}$ Karena, manusia tidak dapat datang kepada Allah, sebab manusia telah jatuh ke dalam dosa, ketika Adam telah memakan buah terlarang di taman Eden.

Oleh sebab itu, Allah mengunakan bahasa yang dapat dimengerti oleh manusia, sehingga maksud Allah dapat ditangkap olehnya, karena manusia adalah mahluk yang terbatas. Bahasa tersebut adalah bahasa metafora, bahasa temporer manusia ${ }^{59}$ dan juga dengan mengunakan analogi dan antrophormisme ${ }^{60}$. Penyingkapan apa yang terdapat di dalam diri Allah ini disebut dengan opera ad extra. Penyingkapan ini ditulis di dalam Alkitab. Penyataan diri Allah ini disebut dengan wahyu (revelation).

Wahyu Allah tersebut terbagi atas dua bagian, yaitu wahyu umum dan wahyu khusus. Wahyu Allah secara umum adalah: melalui ciptaan seperti alam semesta dan hukum-hukum alam yang terdapat didalamnya.Wahyu umum ini hanya menyadarkan manusia, bahwa Allah itu ada. Akan tetapi, wahyu ini tidak dapat menyelamatkan manusia. Oleh sebab itu, Allah memberikan penyataan khusus atau wahyu khusus kepada manusia, sehingga manusia dapat mengenal-Nya, mengerti akan kehendak-Nya dan memperoleh keselamatan yang daripada-Nya.

Wahyu khusus ${ }^{61}$ adalah penyataan Allah secara khusus kepada manusia, dengan cara yang khusus, yaitu penyelamatan yang dianugerahkan Allah kepada orang percaya, melalui Yesus Kristus yang mati di kayu salib. ${ }^{62}$ Allah dengan kedaulatan-Nya ingin menyelamatkan manusia dari dosa melalui wahyu khusus ini.

\section{Ibid.}

59 Bloesch, Holy ..., 28.

60 Spykman, Reformational, 75. Van Til, yang menyatakan bahwa analogi itu adalah refleksi dan juga re-intrepetasi pengetahuan yang dari pada Allah. Sebab, pengetahuan manusia berasal dari pada-Nya (Cornelius Van Til, An Introduction to Systematic Theology (Phillipsburg: Presbyterian and Reformed Publhishing Co., 1982) 12.

${ }^{61}$ Van Till menyatakan bahwa wahyu khusus melalui teophani, nubuat, mukjizat, inkarnasi dan Alkitab.

${ }^{62}$ Togardo Siburian, Class Note: Prologomena (Bandung: STTB, 2010) 7. 
Wahyu khusus ini terbagi atas dua bagian: 1) inkarnasi; 2) inskripturasi.

\section{Inkarnasi Yesus Kristus}

Kristus yang adalah salah satu pribadi dari Tritunggal datang berinkarnasi menjadi manusia. Ia mengambil rupa bentuk menjadi daging. Ia adalah Logos yang menjadi manusia. Kristus adalah puncak dari wahyu Allah, didalamnya seluruh janji akan keselamatan yang daripada Allah terwujud di dalam-Nya.

Firman Allah hanya satu, yaitu keselamatan di dalam Yesus Kristus. ${ }^{63} \mathrm{Hal}$ ini telah digenapi di dalam inkarnasi Kristus di dalam dunia. Firman Allah yang tunggal ini merupakan kehendak-Nya yang tidak berubah.

Ucapan atau firman Allah dan tindakan atau perbuatan-Nya adalah suatu kesatuan, terkait satu dengan yang lain, sehingga tidak terpisahkan. ${ }^{64}$ Allah berfirman untuk menyelamatkan manusia yang berdosa dan Ia langsung bertindak, yaitu melalui inkarnasi Kristus, sehingga Ia sendiri yang datang kepada manusia.

Wahyu yang diinskripturasikan melalui pengilhaman Roh Kudus

Wahyu khusus inskripturasi merupakan firman Allah yang dituliskan di dalam Alkitab, melalui inspirasi (pengilhaman) oleh Roh Kudus kepada penulis Alkitab secara organik (yaitu Allah menggunakan apa yang ada pada dirinya penulis kitab, seperti latar belakang, pendidikan dan yang lain).

Allah mengkomunikasikan rencana dan ketetapan yang terdapat di dalam diri-Nya (opera ad intra) yaitu rancangan keselamatan, yang dinyatakan dengan kata-kata proposional ${ }^{65}$ yang tidak saling kontradiksi satu dengan yang lain, baik di dalam Perjanjian Lama maupun Perjanjian Baru. Kebenaran proposional merupakan suatu kebenaran yang diungkapkan atau dikalimatkan

\footnotetext{
${ }^{63}$ Spykman, Reformational ..., 79.

${ }^{64}$ Bloesch, Holy.

${ }^{65}$ Siburian, Prologomena ..., 7.
} 
dalam bahasa manusia, yang bersifat rasional, kognitif, sehingga dapat dimengerti dan ditelaah oleh manusia. ${ }^{66}$

Alkitab bukanlah langsung diberikan oleh Allah dari surga, melainkan diturunkan melalui pengilhaman Roh Kudus, dengan menggunakan bahasa yang dimengerti manusia dan yang sesuai dengan konteks jamannya. Oleh sebab itu, Alkitab perlu ditafsirkan dengan benar dan tidak boleh ditafsir secara leteralisasi, sehingga akan menyebabkan kesalahan penafsiran.

\section{Konsep Injili Tentang Ketidakterbatasan Allah}

Allah adalah Allah yang tidak terbatas, oleh apapun yang ada, bahkan Ia tidak dapat dibatasi oleh siapa pun. Ketidakterbatasan Allah berhubungan dengan aseity-Nya, yang mana ia tidak disebabkan oleh siapa pun dan tidak memiliki penyebab. Hal ini menyangkut kemahakuasaan, eksistensi, esensi, maupun atribut dan juga pekerjaan-Nya. Hal ini menunjukkan ketidakterbatasan-Nya sebagai Allah.

\section{Dasar-dasar ketidakterbatasan Allah}

Allah adalah tidak terbatas, yang mana dasar dari ketidakterbatasan-Nya adalah:

\section{Lordship atau Ketuhanan dari Allah}

Ketuhanan atau Lordship yaitu bahwa Ia adalah satu-satu-Nya Allah, yang mahakuasa maupun yang tidak terbatas. ${ }^{67}$ Ketuhanan Allah tersebut dapat dilihat dari: a) kontrol, yang artinya adalah Allah memiliki kuasa untuk mengatur seluruh alam semesta ciptaan-Nya, sesuai dengan kehendak-Nya. kontrol Allah melampaui segalanya, sehingga tidak terbatas (Kel.20:3; Ul.6:4); dan juga menjangkau seluruh aspek kehidupan dari manusia. ${ }^{68}$ Dengan

66 Ibid.

${ }^{67}$ Frame, The Doctrine ..., 47-76.

68 Frame, Doktrin Pengetahuan tentang Allah, OBjek Pengetahuan dan Justifikasi Pengetabuan (Malang: SAAT, 2004) 28. 
demikian, kontrol Allah mencakup dunia natural (Kej.1:1-31; Kel.20:11; Yer.10:12); sejarah manusia; (individual buman lives); keputusan manusia; maupun anugerah keselamatan. b) Otoritas Allah, yang artinya adalah Ia berhak untuk untuk melakukan perintah, dan melakukan apa yang seharusnya dilakukan oleh manusia ciptaan-Nya, sebab Ia adalah Allah. ${ }^{69}$ Otoritas Allah tersebut adalah: 1) mutlak atau absolut, sehingga tidak dapat dipertanyakan. Ia tidak dapat diuji oleh manusia; 2) keabsolutan dari otoritas Allah adalah dalam pengertian perjanjian yang melampaui dari kesetiaan manusia. Oleh sebab itu, hanya ada Allah dan tidak boleh ada yang lain, selain daripada-Nya; 3) otoritas Allah mencakup seluruh area dari kehidupan umat-Nya. Otoritas Allah tersebut di dalam sejarah penyelamatan, dunia dan yang lainnya; c) Allah juga hadir di dalam kehidupan umat-Nya. Ia bukanlah hanya transenden, yang jauh terpisah dari umat-Nya, namun juga Ia hadir di dalam kehidupan umat-Nya, untuk menopang dan memeliharanya.

\section{Kedaulatan Allah yang tidak terbatas}

Dasar kedua dari ketidak terbatasan Allah adalah kedaulatanNya, yang artinya adalah supremasi, martabat sebagai raja (kingship) dan ketuhanan dari Allah. ${ }^{70}$ Kedaulatan Allah menunjukkan: ${ }^{71}$ Ia adalah Tuhan; Yang Maha Tinggi yang melakukan sesuai dengan kehendak-Nya (Mzm.115:3); Ia Maha Kuasa, yang memiliki surga dan bumi; Ia mengatur bangsa-bangsa, yang menentukan turun naiknya raja, pemimpin, berdirinya dan jatuhnya suatu kerajaan maupun negara (Mzm.22:28); Ia adalah Raja atas segala raja (1Tim.6:15); Ia adalah hukum atas diri-Nya sendiri.

Kedaulatan Allah adalah absolut atau mutlak, tidak dapat dilawan dan juga tidak terbatas. Kedaulatan Allah ini merupakan sifat dari keseluruhan dari Allah, baik esensi, atribut, eksistensi-

${ }^{69}$ Frame, The Doctrine ..., 80.

70 Arthur Pink, The Sovereign of God (Michihgan: Baker Book House, 1986) 19. 
Nya, yang mana: ${ }^{72}$ 1) kedaulatan Allah menjalankan atau melakukan kuasa-Nya; 2) kedaulatan-Nya untuk melakukan atau mengadakan belas kasihan-Nya kepada manusia; 3) kedaulatan untuk melakukan atau mengadakan kasih-Nya; 4) kedaulatan untuk melakukan atau melaksanakan anugerah-Nya kepada siapa ditujukan atau diberikan.

Kedaulatan Allah merupakan suatu bagian dari atribut-Nya. Ia berdaulat atas segala sesuatu, sebab Ia menciptakan segala dan segala sesuatu berasal daripada-Nya. Oleh sebab itu, Ia berhak atas ciptaan-Nya dan melakukan apa saja sesuai dengan kehendak-Nya yang mutlak (Da.4:35; 6:16). ${ }^{73}$

Oleh sebab itu, kedaulatan Allah yang mutlak ini menunjukkan bahwa: kehendak-Nya mutlak ${ }^{74}$; kekuasaan Allah yang sempurna ${ }^{75}$; dan anuerah-Nya yang berdaulat.

\section{Prinsip-Prinsip Ketidakterbatasan Allah}

\section{Allah yang tidak dapat dipengaruhi oleh apa pun}

Aseity atau aseitas yang artinya bermula dari dirinya sendiri. ${ }^{76}$ Aseitas merupakan self eksistance atau Allah ada di dalam diri-Nya sendiri atau Ia berdiri sendiri. Ia tidak disebabkan oleh siapapun, sebab Ia adalah penyebab dari segala yang ada di dalam semesta ini. Oleh sebab itu, ciptaan bergantung kepada-Nya.

Allah tidak memproduksi diri-Nya sendiri, karena Ia bukanlah hasil dari produksi apapun. Ia ada alasan untuk keberadaan-Nya dan makna untuk diri-Nya sendiri. ${ }^{77}$ Oleh sebab itu, Ia adalah absolut atau mutlak, yang ada pada diri-Nya sendiri. Ia adalah Allah yang tidak terbatas dan tiada yang dapat membatasi-Nya.

72 Ibid, 21-27.

73 Bavink, God ..., 228-229.

74 Berkhof, Doktrin ..., 310.

75 Ibid, 136.

76 Berkhof, Teologi ..., 91.

77 Cornelius Van Til, An Introduction to Systematic Theology (Phillipsburg: Presbyterian and Reformed Publishing Co., 1982) 206. 


\section{Allah ada sebelum ciptaan eksis}

Alam semesta atau dunia dan yang segala isinya adalah terbatas, karena ia adalah ciptaan dari Allah. Oleh sebab itu, pencipta dari segala sesuatu tersebut adalah sesuatu yang tidak terbatas, sebab Ia adalah sumber dari segala sesuatu yang ada tersebut.

Hal inilah yang menunjukkan keberadaan Allah, sebelum dunia ini dijadikan atau diciptakan. Sebelumnya, Allah telah merancangkannya atau memutuskannya di dalam diri-Nya atau di dalam opera ad intra. Kemudian, apa yang telah diputuskannya tersebut, yaitu penciptaan-Nya terlaksana. Allah melakukannya dengan dengan kedaulatan-Nya yang otoritas, berkuasa dan mutlak.

\section{Dekrit Allah yang tidak pernah gagal}

Prinsip selanjutnya dari ketidakberubahan Allah adalah dekritNya. Dekrit Allah adalah rencana Allah yang kekal terjadi sebelum dunia dijadikan, melaluinya Ia menentukan segala sesuatu sebelum terjadi. $^{78}$

Dekrit Allah merupakan pikiran atau rencana Allah yang ada di dalam diri-Nya atau opera ad intra, yang dinyatakan oleh-Nya kepada manusia melalui firman yang disampaikan, baik melalui utusannya seperti nabi maupun rasul-Nya, yang mana ditelah diinskripturasikan. Dengan demikian, manusia dapat mengetahui sebagian apa yang telah direncanakan oleh-Nya.

Natur dari dekrit atau dekrit Allah ini adalah: ${ }^{79}$ 1) ketetapan ilahi adalah satu. Ketetapan Allah tidak banyak, namun satu untuk selamanya, yang mana sekali ditetapkan dan sekaligus akan terjadi, mencakup keseluruhan. Ia merupakan suatu kesatuan yang tidak terpisahkan ${ }^{80}$;2) hubungan antara ketetapan dan pengetahuan Allah. Allah menetapkan ketetapan atau dekrit-Nya bukan

${ }^{80}$ Siburian, Class Note: Doktrin. Allah, (Bandung: STTB, 2011). 
berdasarkan foreknowledge-Nya, akan tetapi berdasarkan ketetapanNya; 3) ketetapan berhubungan baik dengan Allah maupun manusia. Ketetapan Allah tersebut mencakup juga dari manusia yang adalah mahluk ciptaan-Nya; 4) ketetapan untuk bertindak dan bukanlah tindakan itu sendiri. Ketetapan Allah bukanlah untuk ciptaan atau ketetapan itu sendiri, melainkan perwujudkan dari opera ad intra, yang dinyatakan oleh-Nya (opera ad extra), sehingga dapat diketahui oleh manusia; Ketetapan Allah ini berhubungan dengan apa yang akan dilakukan oleh-Nya, yaitu menciptakan, memelihara, mengarahkan dan menebus. ${ }^{81}$

Dekrit Allah ini adalah berdasarkan diri dan kedaulatan-Nya. Kedaulatan Allah tersebut adalah kedaulatan sejak kekal untuk menetapkan apa yang terjadi dan melakukan kehendak-Nya atas ciptaan yang sesuai dengan apa yang telah ditetapkan-Nya sejak semula. ${ }^{82} \mathrm{Hal}$ ini merupakan landasan dari dekrit Allah, yang mana tujuan-Nya adalah untuk kemuliaan-Nya. ${ }^{83}$

Dengan demikian, Allah tidak dapat dibatasi oleh apapun dengan apapun yang terjadi dan apa yang akan terjadi. Karena, sesuatu yang akan terjadi sebelumnya telah ditentukan oleh Allah.

\section{Kemahakuasaan Allah yang Tidak Terbatas}

Allah adalah mahakuasa. kuasa-Nya tidak terbatas dan absolut atau mutlak. Apa yang Dia kehendaki, inginkan, rancangkan dan tetapkan akan terjadi. Hal tersebut dengan sebutan-sebutan (atau nama) yang diberikan kepada Allah seperti: El Shaddai, Allah yang mahakuasa. El ${ }^{84}$ menekankan akan: ${ }^{85}$ kuasa dan kekuatan dari pada

${ }^{81}$ Millard J. Erickson, Christian Theology (Grand Rapids: Baker Book House, 1986) 353.

82 Siburian, Class Note: Doktrin.

${ }^{83}$ Charles Hodge, "The Decree of God," dalam The Living God, (ed) Millard J. Erickson (Eugene: Wipf \&Stock Publishers, 1999) 458.

${ }^{84}$ Nama ini merupakan nama dewa tertinggi orang Kanaan, yang digunakan oleh orang Israel dan dipakai di dalam alkitab, yang digunakan untuk menyebut nama Allah. Akan tetapi, arti atau makna dari nama tersebut sudah berubah (Ibid).

${ }^{85}$ Bavink, God ..., 97. 
Allah. Dia adalah Allah yang kuat dan maha kuasa, yang mana Ia adalah tidak terbatas. Elohim yang diterjemahkan ke dalam bahasa Yunani sebagai Theos dan Inggris sebagai God; bahasa Indonesia sebagai Allah. Kata ini menunjuk pada Allah secara umum. Nama ini menunjukkan bahwa Allah itu adalah mahakuasa. Bentuk jamak dari kata ini adalah untuk menunjukkan kemuliaan-Nya besar.

Kemahakuasaan Allah: ${ }^{86}$ 1) dapat melakukan apa saja yang diinginkan olehnya; 2) kekuasaan Allah tidak terbatas; 3) Allah memiliki kekuatan apapun untuk melakukan apa saja; 4) kemahakuasaan Allah melebihi kuasa apapun.

Allah adalah mahakuasa. Karena, seorangpun tidak dapat melihat wajah-Nya (Ul.7:2; Kel.33:20); kekuatan dan kuasa-Nya sangat besar (Ayb.9:4; 36:5), yang mana Ia pemilik dan memerintah langit dan bumi dengan otoritas-Nya (Kel.15:18; Maz.29:10); Allah mahabesar, berdaulat dan Raja yang besar (Mat.5:35; 1Tim.1:17). ${ }^{87}$

Kemahakuasaan Allah dapat dilihat dari semua pekerjaan-Nya, penciptaan, pemeliharaan Allah, pembebasan bangsa Israel keluar dari Mesir (Yes.40:26). Di samping itu, seluruh atribut Allah menunjukkan kemahakuasaan-Nya.

\section{Ketidakterbatasan Allah yang Luar Biasa}

Allah yang tidak terbatas adalah yang tidak dapat dibatasi oleh apapun. Hal ini berhubungan dengan esensi-Nya bahwa Ia adalah Roh yang bukan immaterial. Ia yang tidak terbatas, dapat masuk ke dalam sesuatu yang terbatas. ${ }^{88}$ Hal ini merupakan bagian dari ketidakterbatasan-Nya. Oleh sebab itu, ketidakterbatasan Allah dapat dilihat dari atribut-atribut-Nya seperti: 1) Kesempurnaan Allah, yang tidak mengalami perubahan ${ }^{89}$; 2) kekekalan Allah, yang mana Ia tidak dapat musnah atau hancur, seperti ciptaan-Nya yang

${ }^{86}$ Frame, The Doctrine ..., 521-522.

${ }^{87}$ Bavink, God ..., 245-246.

88 Donald G. Bloesch, God The Almighty, Power, Wisdom, Holiness, Love (Downers Grove: InterVarsity Press, 1995) 85.

${ }^{89}$ Berkhof, Doktrin ..., 97. 
akan musnah dan binasa (Mzm.102:25-27) ${ }^{90}$; 3) kemahatahuan Allah, mengetahui masa lalu, masa sekarang, maupun masa depan atau apa yang akan terjadi. Dasar dari kemahatahuan Allah adalah dekrit-Nya, sebab segala sesuatu yang akan terjadi sudah ditetapkan oleh-Nya di dalam kekekalan. Kemahatahuan Allah tidak berdasarkan pra-pengetahuan-Nya (foreknowledge), yang mana sesuatu akan terjadi, berdasarkan pengetahuan yang dimiliki-Nya. Oleh sebab itu, Allah tidak dapat dibatasi oleh apa yang akan terjadi atau yang tidak akan terjadi, sebab segala sesuatu ada di bawah kontrol-Nya; 4) Allah yang tidak dibatasi oleh waktu dan ruang (Omnipresent). Allah adalah mahahadir (Mzm.139:7-10). Ia tidak dapat dilokalisasikan oleh manusia di dalam suatu tempat tertentu, misalnya Allah dibatasi di dalam Bait Suci atau di dalam gedung gereja. $^{91}$ Misalnya melalui pujian dan penyembahan yang dilakukan oleh orang percaya, untuk menghadirkan Allah. Allah tidak memiliki suatu bentuk atau ruang tertentu, sehingga Ia harus berada dalam ruang dan tempat tertentu. ${ }^{92}$ 5) Allah yang tidak berubah (Immutable). Ketidakberubahan Allah artinya adalah Allah sama dari dulu, sekarang dan sampai selama-lamanya, baik esensi, sifat atau atribut, keberadaan, kesempurnaan, tujuan dan janjiNya. ${ }^{93}$ Hal ini merupakan sifat mutlak Allah yang tidak dimiliki oleh mahluk ciptaan-Nya. Allah tidak berubah dari dulu sampai sekarang (Mzm.102:26-28). Allah adalah Allah di dalam diri-Nya sendiri; keberadaan, keputusan, rencana, kehendak-Nya tidak berubah; Allah tidak memerlukan pertobatan, seperti manusia yang perlu bertobat dari tindakannya; Apa yang dikatakan oleh Allah, akan dilakukan-Nya (Bil.15:28); panggilan dan karunia serta ketetapan dan rencana-Nya tidak dapat dibatalkan dan berubah; Ia

90 Ibid, 97.

${ }^{91}$ Erikson, Christian ..., 273.

92 Wayne Grudem, Systematic Theology, An Introduction to Biblical Doctrine (Grand Rapids: Zondervan Publishing House, 1994) 173.

93 Herman Bavink, Reformed Dogmatics, God and Creation, Vol.II., (Grand Rapids: Baker Academics, 2003) 38. 
menyempurnakan apa yang telah dibangun-Nya. ${ }^{94}$ Ketidakberubahan Allah menunjukkan kesempurnaan maupun ketidakterbatasan-Nya.

Oleh sebab itu, Allah itu tidak mengalami perubahan seperti manusia yang mengalami perubahan dan pertumbuhan. Allah juga tidak dapat diubah oleh siapapun. Ia tetap sama dari dulu, sekarang dan sampai selamanya. Hal-hal yang tidak berubah di dalam diri Allah: (a) hikmat Allah yang sempurna ${ }^{95}$; (b) kebijaksanaan Allah yang sempurna ${ }^{96}$; (c) kebaikan Allah kekal dan besar ${ }^{97}$; (d) pribadi Allah yang sempurna ${ }^{98}$. 6) Pekerjaan Allah yang menunjukkan ketidakterbatasan-Nya, yaitu: (a) penciptaan Allah yang mengagumkan; (b) pemeliharaan Allah atas ciptaan (Provedensia) ${ }^{99}$, yaitu pengaturan Allah atas dunia ${ }^{100}$; penjagaan atas ciptaan (preservation) $^{101}$; pemeliharaan khusus Allah Atas orang percaya.

\section{Respons Injili Terhadap Gagasan Limited Godism}

Penyimpangan dari Limited Godism adalah: 1) Anti Gereja tradisional $^{102}$; 2) Kristus yang disembunyikan, karena Kristus yang mati dan tersalib disamarkan. ${ }^{103}$ Kristus yang ditawarkan adalah Kristus yang menyenangkan, lucu, sehingga terjadi penyimpangan didalamnya; 3) Injil tanpa dosa ${ }^{104}$; 4) psikologisasi

94 Ibid, 38.

95 Berkhof, Doktrin ..., 101.

96 Ibid, 114.

${ }^{97}$ Berkhof, Doktrin ..., 121-126.

98 Ibid.

99 Berkhof, Doktrin ..., 317-318.

100 Erickson, Christian ..., 394-398.

101 Frame, The Doctrine ..., 284-285.

102 William Benke dan LeEtta Benke, The Generation Driven Church, Evengalizing Boomers, Busters and Millennials (Cleveland: The Pilgrim Press, 2002) 1 6.

103 Ibid, 33.

104 Dan Bauman, All Originality Makes Dull Church (California: Vision House Publishers, 1976) 67-73. 
daripada.teologi ${ }^{105}$. Tujuannya adalah untuk menyentuh perasaan dari mereka.

\section{Penilaian Injili terhadap Gagasan Limited Godism}

Penilaian Injili terhadap Limited Godism adalah:

1. Terjebak dalam antroposentrisme yaitu yang berpusatkan pada diri sendiri. Segala sesuatu diukur oleh manusia itu sendiri;

2. Pengalaman spektakuler menjadi ukuran dalam segala sesuatu $^{106}$ : a) ajaran atau doktrin di dalam kehidupan keagamaan, sehingga orang percaya atau orang Kristen dapat mengalaminya. Pengalaman ini dianggap sebagai suatu dasar yang dapat dijadikan patokan atau ukuran bagi orang percaya untuk mengalaminya; b) Allah yang maha kuasa dan maha hadir dapat sebebas-bebasnya dikendalikan oleh orang percaya untuk dialami di dalam hidupnya. Ia dapat melakukannya melalui doa maupun pujian penyembahan yang dinaikkannya kepada Allah; c) melalui pengalaman yang spektakuler tersebut, orang percaya menyatakan atau mengklaim bahwa ia telah menemukan dan juga mengenal Allah dalam bentuk: kehadiran khusus Allah dalam bentuk manifestasi-manifestasi alkitabiah yang hebat dan luar biasa, melalui pengalaman individu (seperti mukjizat, kesembuhan ilahi yang telah dialaminya), peristiwa alam dan juga perjalanan sejarah; menerapkan langsung teks atau cerita Alkitab dalam pengalaman pribadinya secara buta dan harfiah atau kata perkata; pengalaman spektakuler yang berasal daripada Allah tersebut dijadikan sebagai dasar atau fondasi maupun prinsip dalam berteologi, sehingga dijadikan sebagai alat untuk menciptakan konsep baru tentang Allah (atau yang disebut dengan menciptakan Allah-Allah yang baru) dan dijadikan sebagai paradigma untuk menciptakan ilah-ilah palsu.

105 G.A. Pritchard, Willow Creek Seeker Service, Evaluation A New Way of Doing Church (Grand Rapids: Baker Books, 1995) 273.

106 Togardo Siburian, Isu-Isu Kontemporer dalam Doktrin Allah, Classnote, STTB (Indonesia) Bandung 2009. 
3. Berdasarkan prinsip ini, maka kehadiran Allah yang maha kuasa dapat dirasakan di dalam kehidupan orang yang percaya dan dikendalikan olehnya, bahkan dapat dijadikan sebagai wahyu yang otoratif di luar dari pada alkitab. ${ }^{107}$

4. Menciptakan Allah menurut persepsi manusia ${ }^{108}$ sehingga Allah terbatas diciptakan oleh manusia. Caranya menciptakan Allah yang sesuai dengan ciptaan manusia itu adalah. ${ }^{109}$

5. Manusia yang berkuasa mengantikan Allah, sebab Allah telah berubah menjadi budak atau hamba untuk melayani kebutuhan dari manusia.

6. Pemutarbalikan prinsip iman Alkitabiah. ${ }^{110}$ Iman alkitab mengungkapkan bahwa Allah menciptakan manusia menurut gambar dan rupa-Nya (Kej.1:27). Namun, hal itu telah dibalikkan oleh manusia menjadi manusia menciptakan Allah menurut gambar dan imagenya sendiri.

7. materialisasi konsep Allah: a) Allah yang mahakuasa menjadi Allah yang terbatas; b) Allah menjadi impersonal ${ }^{111}$, sebab Allah telah dijadikan hanya sebagai energi atau kuasa yang memberikan kemudahan bagi manusia; c) Allah dilokalisir oleh Limited Godism. Hal ini dapat dilakukan melalui pujian dan penyembahan yang dilakukan olehnya di dalam ibadah orang percaya. Misalnya adalah dengan Toronto Blessing, yang mana Allah dilokalisir di dalam tempat atau ibadah. Maka, orang percaya dapat melokalisir Allah di dalamnya. Allah akan dianggap hadir, melalui permainan perasaan,yang mana akan merasakan suatu perasaan yang agak asing atau aneh yang akan dialaminya; d) memberhalakan kehadiran dan pengalaman dengan Allah. Allah dianggap kurang penting bagi 2004).

107 Hans Maris, Gerakan Karismatik dan Gereja Kita (Surabaya: Momentum,

108 Norman L. Geisler, Creating God In The Image of Man? (Minneapolis: Bethany House Publishers, 1996).

109 Morrey, Battle ..., 25-27.

110 Ibid, 91.

111 Douglas S. Huffman dan Eric L. Johnson, "Should the God of Historic Christianity Be Replaced?” dalam "God Under Fire, (eds) Douglas S. Huffman dan Eric L. Johnson (Michigan: Grand Rapids, 2002) 35. 
gagasan Limited Godism, sebab yang penting adalah kehadiran-Nya ataupun pengalaman spektakuler-Nya. Oleh sebab itu, pengalaman dan kehadadiran Allah yang selalu dikejar dan dicari. Allah itu sendiri sebagai sumber dari segala sesuatu diabaikan olehnya.

8. Humanisasi konsep Allah: a) Allah dapat berubah oleh bujukan dan rayuan manusia, yang dilakukan melalui doa, pujian dan penyembahan. Hal ini dianalogikan seperti seorang anak kecil yang sedang merayu ayahnya, dengan cara memuji, dan memeluk ayahnya untuk mengharapkan sesuatu darinya. Ayahnya akan senang dan akan memberikan apa yang akan diharapkan oleh anaknya. Demikian juga dengan Allah, Ia dapat dibujuk dan dirayu oleh manusia, sehingga dapat berubah. Demikian besarnya, pengaruh manusia terhadap Allah, sehingga dapat mengubah-Nya; b) Allah membutuhkan manusia. Oleh sebab itu, Allah bekerjasama dengan manusia untuk melakukan apa yang akan direncanakan maupun apa yang telah diputuskan oleh-Nya, ${ }^{112}$

9. Literalisasi teks Alkitab, yaitu: a) interpretasi subjektif tentang Allah, sebab mereka menafsirkan Alktitab dengan pengalaman eksistensial, alegorisasi, literalisasi, spiritualisasi, pragmatisme, dengan huruf-huruf di dalam Alkitab. Apa yang ditertulis secara huruf per huruf atau harfiah di dalam Alkitab (literalisasi), itu dianggap sebagai Allah dan Allah harus melakukanNya. Misalnya adalah: adalah nama Allah, haruslah Yhwh, karena itu berasal dari bahasa Ibrani dan dianggap sebagai nama Allah yang telah dipatenkan dan tidak boleh diubah, sehingga Allah dibatasi oleh nama tersebut; peristiwa maupun cerita di dalam alkitab dapat dialami oleh pembaca atau orang percaya pada jaman sekarang;

10. Lompatan iman yang buta (leap of faith). Limited Godism mencari sesuatu pengalaman yang luar biasa atau spektakuler dari

112 Charles E. Gutenson, "Does God Change?" dalam God Under Fire, (eds) Douglas S. Huffman dan Eric L. Johnson (Michigan: Grand Rapids, 2002) 240. 
Allah. Oleh sebab itu, cerita dan pengalaman yang luar biasa dari dalam Alkitab dipercayai atau diimani di dalam hidupnya dengan begitu saja dan dengan huruf perhuruf, sehingga dapat terjadi. Ia mempercayainya dengan sangat yakin atau disebut sebagai lompatan iman, bahkan hal itu dapat diklaimnya sebagai rhema yang daripada Allah;

11. Wahyu baru di luar Alkitab. Pengalaman yang dialami oleh orang percaya bersama dengan Allah, yang didukung oleh teks Alkitab, ini dianggap sesuatu yang rohani atau spiritual dan dianggap sebagai Allah berbicara kepadanya. Peristiwa ini dianggap hampir sama seperti firman Allah yang terdapat di dalam Alkitab, bahkan dapat dianggap sebagai wahyu baru bagi orang percaya;

12. Terjebak dalam spiritisme. Limited Godism sangat haus akan hal yang bersifat spiritual, spektakuler, ajaib dan heran atau disebut dengan hal-hal yang bersifat roh, karena mengejar sesuatu yang ajaib dan roh. Ia mengabaikan peran akal atau rasio, karena selalu mengharapkan yang bersifat spiritisme;

13. Pragmatisasi konsep Allah. Allah telah dijadikan sebagai alat dan bukan sebagai tujuan. Manusia mencari apa yang dapat Allah berikan, sehingga bermanfaat baginya. Konsep Allah di dalam pikirannya adalah apa yang penting atau berguna baginya, bila tidak maka Ia tidak akan dicari.

\section{Afirmasi Injili tentang Doktrin Ketidakterbatasan Allah}

\section{Kesempurnaan Allah yang mutlak}

Allah adalah sempurna, yang mana kesempurnaan-Nya meliputi keseluruhan dari diri Allah, baik esensi, eksistensi, atribut, pekerjaan, ketetapan-Nya. Hal ini menunjukkan ketidakterbatasan Allah dan kemahakuasaan-Nya, yaitu:

Allah adalah dasar dari segala sesuatu. Ia mendasari segala sesuatu yang ada, karena Ia yang menciptakan segala sesuatu. Ia adalah penyebab dari segala sesuatu, sehingga dunia ini ada. Ia otonom dan berdiri sendiri dan tidak ada yang menyebabkan diri- 
Nya. Ia tidak membutuhkan dan bergantung kepada siapapun di luar dari diri-Nya (Mzm.145:1-5; Yoh.5:26; Rm.11:33-36). ${ }^{113}$ Oleh sebab itu, tidak ada yang dapat mengatur maupun yang dapat memerintahkan Allah. Sebab, Ia yang mengatur segala sesuatu yang ada di dalam semesta ini, apalagi yang mengatur manusia;

Kedaulatan Allah yang tidak dapat dibantah, yang mana ketidakterbatasan dan kemuliaan Allah ditunjukkan melalui kedaulatan-Nya. ${ }^{114}$ Kedaulatan Allah adalah mutlak dan tidak ada seorang pun mahluk ciptaan yang dapat membantah-Nya, sebab Ia adalah Allah yang besar dan berkuasa. Kedaulatan Allah berlalu atas segala sesuatu yang ada di dalam semesta ini. Kedaulatan Allah tersebut mencakup kehendak, kuasa, anugerah-Nya. Manusia tidak dapat mengubah kedaulatan Allah, sebab Ia adalah Tuhan memerintah dan menggontrol segala sesuatu yang ada. Dengan demikian, Ia adalah Allah yang tidak terbatas.

Kemahakuasaan Allah melampaui segalanya. Allah adalah mahakuasa, yang mana tidak dapat dikendalikan oleh manusia. Apabila kemahakuasaan Allah dapat dikendalikan oleh manusia, maka ia bukan lagi Allah, sehingga Ia telah berhenti menjadi Allah. Dengan kemahakuasaan-Nya, Allah mengatur segala sesuatu dan dapat pergi kemana pun dikehendaki-Nya. Hal ini menunjukkan ketidakterbatasan daripada Allah yang mahakuasa. Allah tidak terikat oleh apa pun, apalagi oleh ciptaan- $\mathrm{Nya}$ sendiri dan tiada yang dapat mengubah-Nya.

Allah melampaui ruang dan waktu. Ia adalah pencipta segala sesuatu di dalam semesta ini, sehingga ada ruang atau tempat, dan pada saat itu juga ada waktu. Dunia tidak diciptakan di dalam waktu, tetapi waktu ada bersamaan dengannya. ${ }^{115}$ Allah dan ciptaan-Nya adalah sesuatu yang berbeda dan terpisah. Ia adalah Allah transenden, yang terpisah dengan ciptaan-Nya. Oleh sebab

113 Eric dan Johnson, God ..., 35.

114 Ibid., 34.

115 Paul Helm "Is God Bound by Time?, dalam "God Under Fire, (eds) Douglas S. Huffman dan Eric L. Johnson (Michigan: Grand Rapids, 2002) 130. 
itu, Ia tidak terikat dengan ciptaan-Nya, khusus ruang dan waktu; ${ }^{116}$ Dengan demikian, Allah adalah tidak terbatas, Ia tidak terbatas oleh apapun, sebab Allah adalah Roh yang tidak terikat oleh ruang dan waktu manusia yang terbatas. Ia adalah Allah yang kekal, yang mana kekekalan-Nya tidak seperti waktu temporal dari manusia. Oleh sebab itu, Allah tidak dapat ditangkap oleh manusia melalui pujian dan penyembahannya, bahkan tidak dapat menghadirkanNya sesuai dengan kehendaknya sendiri atau mengatur Allah sesuai dengan keinginannya sendiri. Dengan demikian, manusia tidak dapat mengikat Allah di mana pun yang diinginkan olehnya, apalagi di dalam ruang dan waktu yang terbatas.

Kemahatahuan Allah yang tidak terbatas. Oleh sebab itu, Ia mengetahui apa yang telah terjadi masa lalu, masa sekarang dan apa yang akan terjadi di masa depan atau akan datang (Mzm.145:3; Yes.46:9-10; Ibr.4:13). ${ }^{117}$ Kemahatahuan Allah bukan berdasarkan foreknowledge (pra pengetahuan), akan tetapi berdasarkan dekrit-Nya, yang mana segala sesuatu yang akan terjadi berdasarkan dekrit-Nya. Hal inilah yang menunjukkan kemahakuasaan dan ketidakterbatasan Allah. Allah mengetahui apa yang dibutuhkan oleh manusia dan semesta ini, sehingga Ia menopang segala sesuatu dan memelihara-Nya, khususnya manusia. Dengan demikian, manusia dapat hidup, karena ketergantungannya kepada Allah. Oleh sebab itu, manusia tidak dapat membatasi Allah dengan kekuasaan-Nya, sebab ia sangat terbatas.

Allah yang Tetap dan Tidak Berubah, yaitu pribadi Allah yang tidak berubah dan juga ketetapan atau dekrit-Nya tidak berubah. Akan tetapi, Limited Godism secara tidak sadar mengungkapkan di dalam tindakan praksisnya sehari-hari bahwa Allah dapat diubah oleh kehendak atau keinginan-nya, melalui bujukan atau rayuan, bahkan paksaannya. Manusia dapat menggerakkan Allah untuk melakukan sesuatu apa yang dikehendakinya. 
Karya Allah sempurna dan tidak bercacat, baik penciptaan dan yang lainnya, bahkan Allah yang memeliharanya. Pemeliharaan khusus Allah atas ciptaan-Nya dengan cara memelihara dan menopangnya, khususnya manusia sebagai ciptaan-Nya. Perlindungan Allah nyata atas orang percaya, yang mana Allah melindungi umat-Nya dari penderitaan, kesengsaraan, dan juga Ia memenuhi segala kebutuhan dari umat-Nya secara khusus. Hal ini dilakukan oleh Allah bukan karena manusia yang memintanya atau memaksa Allah, akan tetapi karena pemeliharaan (providensia Allah) atas umat-Nya, yang dilakukan berdasarkan dekrit, maupun kedaulatan-Nya. Misalnya, mukjizat seperti kesembuhan secara supranatural yang dilakukan oleh Allah, kepada orang percaya merupakan suatu pemeliharaan khusus-Nya atas manusia. Karena, ia memiliki iman yang lemah, sehingga memerlukan sesuatu yang besar atau supranatural dari Allah, sehingga ia mengalaminya. Pengalaman ini dialami, bukan karena ia hebat atau luar biasa, namun karena imannya lemah, sehingga memerlukan pemeliharaan khusus dari Allah; orang percaya yang berdoa dengan sungguhsungguh dan dengan keras, bahkan ia memaksa Allah untuk menjawab doanya. Kadang kala, Allah menjawab doanya, karena belas kasihan khusus (special mercy) daripada Allah. Allah melakukan ini, karena Ia adalah Allah yang baik, dan yang memiliki belas kasihan atas umat-Nya.

Dengan demikian, kesempurnaan Allah adalah mutlak dan Ia tidak terbatas, yang mana tiada yang dapat mengubah dan yang mengatur-Nya. Oleh sebab itu, Ia tidak mengalami perubahan, baik pribadi, ketetapan, keputusan-Nya.

\section{Manusia sebagai ciptaan yang bergantung kepada Allah}

Manusia adalah ciptaan Allah, yang diciptakan menurut gambar dan rupa-Nya. Manusia diciptakan oleh Allah untuk tujuan atau maksud tertentu, yaitu untuk melayani Allah. Oleh sebab itu, manusia bergantung kepada Allah yang telah menciptakan dirinya. 
Dengan demikian, manusia tidak dapat mengatur, mengendalikan dan memerintah Allah sesuai dengan keinginan dirinya sendiri, sebab ia adalah mahluk ciptaan. Sebaliknya, manusia yang diatur, dikendalikan dan diperintah oleh Allah, untuk tujuan dan maksud-Nya. Karena itu, manusia harus menyesuaikan diri dengan kehendak Allah, sebagai penciptanya.

Allah menciptakan manusia dan bukan manusia yang menciptakan Allah. Manusia tidak dapat menciptakan Allah, karena ia adalah ciptaan yang terbatas. Manusia yang menciptakan Allah, adalah manusia yang hendak mengilahikan dirinya sendiri dan ingin serupa dengan Allah. Ia merefleksikan dirinya sendiri, sehingga ia menjadi ilah dan yang dapat mengatur Allah.

\section{Alkitab kanon yang tertutup sebagai sumber doktrin}

Wahyu sebagai Penyataan Allah, yang mana secara inisiatif menyatakan diri-Nya kepada manusia, sebab manusia telah jatuh ke dalam dosa dan tidak dapat menemukan atau menjumpai Allah. Ia ingin menyatakan apa yang terdapat di dalam pikiran-Nya kepada manusia, melalui wahyu-Nya. Penyataan Allah dinyatakan di dalam bahasa yang dimengerti oleh manusia. Allah mengakomodasikan wahyu-Nya kepada manusia yang terbatas, agar manusia dapat mengenal dan mengetahui apa yang Allah inginkan atau kehendaki kepada semua manusia yang terdapat di dunia ini.

Dengan demikian, pewahyuan Allah adalah komunikasi dan bukan pertemuan atau encounter dengan Allah yang dialami oleh manusia secara subjektif. ${ }^{118}$ Akan tetapi, pewahyuan Allah merupakan komunikasi Allah kepada manusia, yang mana dekritNya dalam opera an intra dinyatakan oleh-Nya. Dengan demikian, pengalaman pribadi yang subjektif tersebut tidak dapat membatasi, mengikat dan memaksa Allah untuk hadir terhadap manusia, karena akan merusak omnipresence Allah. 
Alkitab tidak diturunkan langsung oleh Allah atau Allah sendiri yang menulis Alkitab tersebut, sehingga harus ditafsirkan secara literal atau diliteralisasikan. Akan tetapi, wahyu tersebut diturunkan oleh Allah melalui Roh Kudus yang menginspirasikannya kepada manusia, yaitu dengan pengilhaman organik. Allah menggunakan manusia yang lemah dan terbatas untuk menuliskan wahyu-Nya, dengan apa yang dimiliki oleh manusia tersebut, seperti kepribadian, pendidikan, latar belakang. Namun, penulisan wahyu tersebut atas pengawasan dari Allah, sehingga ia tidak dapat salah. ${ }^{119}$

Semua kata-kata yang ditulis dalam Alkitab diinspirasikan oleh Allah, meskipun penulis Alkitab mengumpulkan banyak fakta-fakta dari sejarah dan meneliti secara seksama (Luk.1) dan yang lainnya, akan tetapi atas pengawasan dan perlindungan dari Allah. Wahyu Allah tersebut bersifat proposisional, yang kognitif dan yang dapat diterjemahkan ke dalam berbagai bahasa di dunia ini. Hal ini terjadi sampai dikanonkan.

Oleh sebab itu, Alkitab sudah tertutup dan tidak ada lagi wahyu yang baru di luar Alkitab yang telah dikanonkan, seperti ungkapan Limited Godism, yang dapat memperoleh wahyu baru (rhema) melalui pengalaman spektakulernya bersama dengan Allah. Kitab yang telah dikanonkan adalah 37 kitab dari Perjanjian Lama dan 26 Perjanjian Baru, sehingga berjumlah 66 kitab.

Hal inilah yang menjadikan Alkitab berotoritas dan normatif atas kehidupan orang percaya. Sebab, ia adalah firman Allah yang telah dinyatakan kepada manusia dan penyataan khusus Allah tentang diri-Nya. Oleh sebab itu, Alkitab menjadi sumber utama di dalam pengajaran atau teologi tentang Allah dan bukan berasal dari persepsi manusia melalui pengalaman spiritual bersama denganNya ataupun pengalaman spektakuler seperti mukjizat kesembuhan yang daripada Allah.

119 Togardo Siburian, Sola Scriptura, Kumpulan Refleksi Kontemporer Atas Tematema Bibliologis (Bandung: STTB, 2005), . 
Untuk mengetahui dan mengenal tentang Allah yang benar, hanya dapat diperoleh dari Alkitab, atau firman Allah yang telah diinskripturasikan oleh Allah, melalui pekerjaan Roh Kudus dan bukan melalui pengalaman maupun dengan persepsi manusia.

Hal inilah yang menjadi sistem teologi di dalam kekristenan, yaitu: firman Allah yang tunggal: ${ }^{120}$ yaitu keselamatan yang datang daripada Allah, di dalam Kristus yang telah mati disalib. Seluruh ayat di dalam Alkitab harus ditafsirkan di dalam terang tersebut atau sistem tersebut. Keselamatan merupakan puncak dari wahyu Allah di dalam Kristus Yesus ${ }^{121}$; wahyu diilhamkan oleh Allah secara rasional dan proposisional, sehingga dapat dimengerti oleh manusia dan didalamnya tidak saling bertentangan satu dengan yang lain; alktiab menafsirkan dirinya sendiri (Sciptura Scripturae interpres). ${ }^{122}$

Oleh sebab itu, hermeneutika sangat penting dilakukan, yaitu untuk menafsirkan apa yang diterdapat di dalam Alkitab, yaitu untuk menemukan pesan asli dari penulis. ${ }^{123}$ Hermeneutika merupakan ilmu menafsirkan Alkitab, dan ketika dilakukan atau dilaksanakan, maka ini yang disebut sebagai eksegesa.

Di dalam menafsirkan Alkitab, keseluruhan dari teks atau perlu untuk dilihat. Pendekatan yang dilakukan adalah grammatical bistory, ${ }^{124}$ yaitu tata bahasa dari teks atau grammar, dan juga sejarah, yaitu dengan melihat konteks dari alkitab, ${ }^{125}$ yaitu konteks segera (alinea atau perikop); konteks kitab, di mana kitab tersebut ditemukan; konteks tubuh, yaitu yang pararel dengan kitab tersebut; konteks kanonik (Perjanjian Lama dan Perjanjian Baru); konteks komunitas atau gereja.

120 Vern S. Poythress, God, Centered Bibblical Interpretation, (Philipsburg: P \& R Publishing Companya, 1999) 58.

121 Joseph Tong, "Sejarah Keselamatan dalam Hermeneutika Alkitab" dalam Sola Scriptura dan Pergumulannya Masa Kini (ed) Togardo Siburian (Bandung: ST'TB, 2005) 3.

122 Bloesch, Holy ..., 193.

123 Bloesch, Holy ..., 174.

124 Ibid.

125 Siburian, Sola ..., 21. 
Eksegesa tidak berhenti sampai di sini, namun ia harus direlevansikan dengan kehidupan pada masa kini, yaitu untuk memecahkan masalah kehidupan, moral dan sosial yang dihadapi oleh masyarakat pada masa kini. ${ }^{126}$ Dengan demikian, firman Allah berbicara kepada manusia pada saat ini.

Oleh sebab itu, Alkitab tidak boleh ditafsirkan secara literalisasi, alegorisasi, pragmatisasi, spiritualisasi, yang mana dilakukan berdasarkan pengalaman secara subjektif yang dilakukan oleh Limited Godism, untuk kepentingan dirinya sendiri.

\section{Allah (Teosentris) sebagai worldview Kristen}

World view Kristen adalah bersifat Teosentris, yaitu segala sesuatu berlandaskan Allah, pencipta langit dan bumi, serta manusia. Segala sesuatu adalah berdasarkan Allah dan semua bergantung kepada-Nya. Dasar dari kepercayaan Kristen adalah wahyu yang diinskripturasikan dan iman sebagai anugerah Allah yang dianugerahkan kepada manusia. Hal inilah yang menjadi sistem kebenaran di dalam Kristen.

World view Kristen ini berbeda dengan Limited Godism yang humanistik dan naturalistik, yang mana bersifat anthroposentris. Manusia sebagai ukuran segala sesuatu, yang menciptakan Tuhan menurut persepsi, maupun imagenya sendiri, bahkan dapat mengatur, mengendalikan dan memperalat Allah. Oleh sebab itu, world view Limited Godism yang bersifat antisupranaturalis, ${ }^{127}$ sebab manusia menjadi tuan atas dirinya sendiri.

\section{Kesimpulan}

Gagasan Limited Godism ada di dalam kekekristenan. Ia bukanlah suatu aliran tertentu atau suatu mazhab teologi tertentu. Akan tetapi, ia merupakan masih suatu gagasan yang berkembang di dalam kekristenan dan masuk di dalam semua aliran kekristenan,

126 Bloesch, Holy ..., 174.

${ }^{127}$ Blameres, Mengenal ..., 3. 
khususnya adalah Injili. Oleh sebab itu, ia tidak memiliki sistem teologi atau kebenaran, sehingga ajarannya kurang sehat, bahkan menyimpang. Dia juga tidak memiliki penafsiran Alkitab yang bertanggungjawab, yaitu: dengan pengalaman eksistensialis; literalisasi Alkitab, eisegesis hermeneutik, bibliosentris, tetapi tidak skriptural, spiritualisasi alkitab dan pragmatisasi praktis untuk keuntungan pribadi.

Limited Godism menyatakan untuk tidak membatasi kuasa Allah, justru sebaliknya ia telah membatasi kuasa Allah di dalam perbuatan atau tindakannya sehari-hari. Ia berusaha untuk mencari dan mengalami pengalaman-pengalaman yang spektakuler bersama dengan Allah, maka ia membatasi Allah dengan pengalaman eksistensinya, yang mana Allah ditangkap didalamnya, yang mana wajib untuk hadir di dalam dirinya, misalnya dengan pujian dan penyembahannya. Hal inilah perjumpaan pribadinya bersama dengan -Nya, sehingga memuaskan dirinya secara pribadi. Melalui ini, manusia akan memperoleh wahyu yang baru, apabila didukung oleh teks Alkitab.

Oleh sebab itu, Allah hanya diperalat dan dijadikan budak oleh manusia, demi kepentingan manusia itu sendiri dan untuk memuaskan hasrat pribadinya secara spiritual dan juga untuk menjawab semua kebutuhan pribadinya. Allah seolah-olah menjadi mesin ATM, budak atau hamba untuk manusia untuk memenuhi kebutuhannya.

Dengan demikian, Limited Godism menjadi ajaran yang menyimpang dan kurang sehat. Sebab, penafsiran yang superficial; otonomi palsu manusia; world view yang humanistik dan naturalistik, yaitu dalam bentuk: sekularisme, rasionalisme, eksistensialisme dan pragmatisme.

Gagasan Limited Godism telah mereduksi persona Allah, sehingga Allah yang tidak terbatas menjadi Allah yang terbatas; Allah yang mahakuasa tidak lagi menjadi mahakuasa; Allah tidak lagi menjadi Allah, namun menjadi alat dan budak bagi manusia. Apabila telah merusak salah satu atribut Allah, maka seluruh 
persona Allah akan rusak. Oleh sebab itu, oleh sebab itu, konsep tentang Allah Teisme Kristen telah diganti oleh Limited Godism, menjadi Allah yang terbatas oleh kehendak manusia. Hal inilah yang menjadikan Limited Godism telah menyimpang dari Teisme Kristen.

Afirmasi Injili tentang doktrin ketidakterbatasan Allah adalah: kesempurnaan Allah yang mutlak, yang tidak dapat dibatasi dan diperalat oleh manusia. Allah adalah sempurna, yang mana kesempurnaan-Nya meliputi keseluruhan dari diri Allah, baik esensi, eksistensi, atribut, pekerjaan, ketetapan-Nya. Hal ini menunjukkan ketidakterbatasan Allah dan kemahakuasaan-Nya, yaitu: Allah adalah dasar dari segala sesuatu; kedaulatan Allah yang tidak dapat dibatasi, yang mana ketidakterbatasan dan kemuliaan Allah ditunjukkan melalui kedaulatan-Nya yang mutlak; Allah adalah tetap dan tidak berubah, baik pribadi, ketetapan atau dekrit maupun keputusannya; karya Allah yang sempurna, yang mana Ia menopang dan memeliharanya, khususnya dalam pemeliharaan orang umat pilihan-Nya.

Manusia adalah ciptaan yang bergantung kepada Allah dan tidak dapat mengatur-Nya. Manusia diciptakan oleh Allah menurut gambar dan rupa-Nya. Oleh sebab itu, ia adalah mahluk yang lemah dan terbatas, sehingga ia harus bersandar kepada Allah, yang mana ia harus menyesuaikan diri dengan kehendak-Nya dan bukan sebaliknya, ia mengatur Allah.

Alkitab merupakan yang kanon tertutup, sebagai sumber doktrin dan sistem teologi. Alkitab adalah firman Allah, yang mana ia memiliki satu firman, yaitu keselamatan di dalam Kristus. Firman Allah yang bersifat proposisional ini tidak kontradiksi satu dengan yang lain. Ia dapat membuktikan dan menafsirkan dirinya sendiri. Hal inilah yang menjadi sistem teologi dari Injili. Alkitab sudah dikanonkan dan tertutup dengan 39 kitab Perjanjian Lama dan 27 Perjanjian Baru. Dengan demikian, tidak ada lagi wahyu yang baru;

World view Kristen yang berlandaskan Allah (Teosentris), yaitu segala sesuatu berlandaskan Allah, pencipta langit dan bumi, serta 
manusia. Segala sesuatu adalah berdasarkan Allah dan semua bergantung kepada-Nya. Dasar dari kepercayaan Kristen adalah Wahyu yang diinskripturasikan dan iman sebagai anugerah Allah yang dianugerahkan kepada manusia. Hal inilah yang menjadi sistem kebenaran di dalam Kristen. Hal ini bertentang dengan Limited Godism, yang mana wawasan dunianya adalah humanistik dan naturalistik, yang berdasarkan antroposentris. Dengan demikian, segala sesuatu adalah berdasarkan atau berlandaskan Allah, yang mana segala sesuatu adalah untuk kemuliaan-Nya (Soli Deo Glory).

\footnotetext{
AERON FRIOR SIHOMBING mendapatkan gelar S.Th dari ST'T INTI, Bandung dan M.Div. dari STTB Bandung. Sekarang mengajar sebagai dosen tetap di STT SAPPI.
} 